\title{
BASICS OF DEVELOPMENT OF ADVENTURE TOURISM ON SUVA PLANINA
}

\author{
Jelena Milenković*1 \\ " PhD student, University of Belgrade - Faculty of Geography, Belgrade
}

\begin{abstract}
Adventure tourism is one of the fastest growing forms of tourism in the global tourism market. It combines travel, sports and recreation in an open space, and the basic motives are challenge, risk and uncertainty. The mountains are particularly attractive destinations for adventure tourism. According to the geomorphological characteristics of the terrain, Suva Planina offers special benefits for the development of this type of tourism. The aim of the paper is to show that the geographical conditions and resources of Suva Planina are good for adventure tourism development. Based on the applied method of assessing mountaineering trails, it was found that Suva Planina has trails suitable for hiking, mountaineering, alpinism, horse riding and mountain biking. In addition to the above, it is possible to engage in a series of activities which are challenging and interesting for tourists: paragliding, skiing, rafting, kayaking, free climbing, etc. The main problems are inadequate tourism infrastructure and negative demographic trends such as poor population density in the region's most attractive areas, low level of education among residents, predominance of old houses, and lack of workforce. As a result, the implementation of adventure tourism is significantly more difficult.
\end{abstract}

Keywords: adventure tourism, Suva Planina, assessment.

\section{Introduction}

Changes in the global tourism market have influenced the formation of new market niches that show particular interest in sports and physical activities

1 Corresponding author: J. Milenković, PhD student, University of Belgrade - Faculty of Geography, Belgrade;

e-mail: jelenamilenkovic311@gmail.com 
(Стефановић, 2010). As a result, adventure tourism has become highly popular (Jovičić, 2010) and has been growing rapidly in the last 3 decades as tourists are searching for various ways of spending their spare time (Soutar \& Williams, 2009; Lötter, Geldenhuys \& Potgieter, 2012; Vujadinović et al, 2013).

Although many authors are making great efforts in exploring this phenomenon (Buckley, 2010; Carnicelli-Filho et al., 2010; Buckley, 2012; Giddy \& Webb, 2016; Chen, Lin \& Chang, 2017, etc.), a comprehensive definition of adventure tourism has not yet been adopted (UNWTO, 2014). The basic problem of defining adventure tourism lies in the fact that people have different experiences and expectations regarding open-air activities, different individual abilities and skills, independence, and the possession of equipment (Buckley, 2006). According to Buckley (2007), adventure tourism represents a commercialized tour in which the main attraction is open-air activity, which is directly related to the natural characteristics of the terrain, requires special sports or similar equipment and is exciting for tourists. More broadly, this form of tourism combines travel, sports and recreation in the open air (Beedie \& Hudson, 2003). Although the basic motives are challenge and risk (Lăzuran \& Ungureanu, 2014), adventurers must have some psychological and physical preparedness as well as the will to stay in nature and in often unpleasant conditions (Spalević \& Igračev, 2011). According to the goals and requirements of potential tourists, adventure tourism can be divided into "soft" (low risk activities) and "hard" adventure tourism (activities with a high level of risk, exceptional dedication and skills) (Schott, 2007).

The mountains are particularly attractive destinations for adventure tourism, and some authors have chosen them for the domain of their research (Mackenzie \& Kerr, 2012; Rokenes, Schumann \& Rose, 2015; Mu \& Nepal, 2016). Gašović (2017) points out that the fundamentals of mountainous adventure tourism development are a rich, unique and preserved natural environment along with a suitable geographical position for tourists. Serbia is mostly a mountainous country but all the mountains don't have conditions suitable for adventure tourism $(\mathrm{AT})^{2}$. One of the mountains which is suitable is the Suva Planina (which in English translates to The Dry Mountain).

\section{Research methodology}

General and specific methods were used for the assessment of geographical conditions and resources for AT development on Suva Planina. The general methods used in the article are: descriptors, analysis, synthesis, and the cartographic method. The specific method used consists of assessing mountain trails.

2 Further on in this document AT. 
This method (first described by Ferguson in 1998) is based on analyzing existing and potential trails for hiking, mountaineering, alpinism, horse riding and mountain biking. The analysis covers the qualitative and quantitative relief features: minimum and maximum altitude, length, air distance between a trail's beginning and end, denivelation, total climb denivelation, total climb length, average climb and maximum climb (Јоксимовић, 2016, Ferguson, 1998). The average climb is determined by equation:

$$
\mathrm{Us}=\frac{\sum D}{\sum L s} * 100
$$

$\Sigma \mathrm{D}$ - total climb denivelation; $\Sigma \mathrm{Ls}$ - total climb length. The purpose of the path is determined according to the standards for use, which are presented in Table 1.

Table 1. Standards for arranging mountain trails according to the purpose of use

\begin{tabular}{|c|c|c|}
\hline Type of trail & Acceptable inclination & Explanation \\
\hline $\begin{array}{c}\text { mountaineering, } \\
\text { hiking, } \\
\text { alpinism }\end{array}$ & $<15 \%$ & includes a constant climb \\
\cline { 2 - 3 } & $<30 \%$ & valid for shorter trails (up to $3 \mathrm{~km}$ ) \\
\hline \multirow{2}{*}{ riding } & $<9 \%$ & $\begin{array}{c}\text { keep a steady grade with small breaks } \\
\text { where slope }<5 \%\end{array}$ \\
\cline { 2 - 3 } & $<15 \%$ & valid for shorter trails (up to $3 \mathrm{~km}$ ) \\
\hline \multirow{2}{*}{ mountain biking } & $<15 \%$ & except on clay and soggy lands \\
\cline { 2 - 3 } & $>15 \%$ & a wider trail to push a bike \\
\hline
\end{tabular}

Source: Јоксимовић, М., 2016

Geographic information systems were used to obtain quantitative data. Mountain trails were drawn in the Global Mapper software package in order to obtain numerical data for mountain trail assessment methods.

\section{Physical-geographical features of Suva Planina}

Suva Planina (The Dry Mountain) belongs to the southwest part of the Carpathian-Balkan mountain system (Краснић, 2005). Its total length is about $45 \mathrm{~km}$ and maximum width is $15 \mathrm{~km}$ (Trajković, Trajković \& Ivanković, 2013). It's bounded by the Nišava river in the north and by the Koritnica-lužnica valley in the north-east and east directions. The Zaplanjska structural basin is located in the south and south-west sides. It's administratively located in the territory of the of the Niška Banja, Gadžin Han and Bela Palanka municipalities (Петровић, 1954). 
Suva Planina belongs to the Fold Mountains (Краснић, 2005) and it represents a large anticline that was formed during Alpine orogenesis. This anticline was destroyed in the northwest and its core was discovered. The core is composed of Permian red sandstone, clay, conglomerates and Paleozoic shale (Милић, 1962). The basic geological structure consists of limestone (about 2/3) (Петровић, 1954).

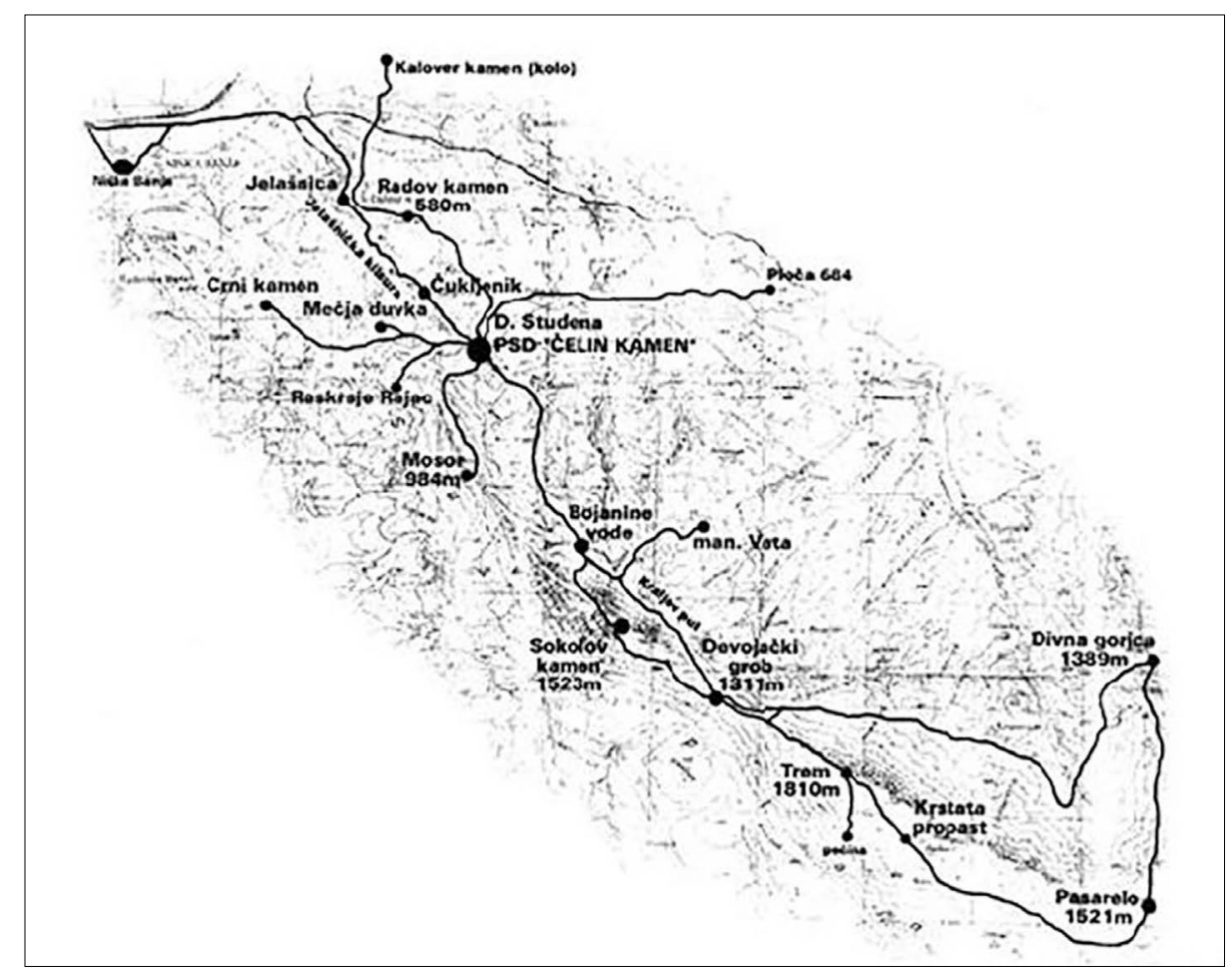

Figure 1. Peaks of Suva Planina

(Source: EkoSpark, 2018)

Two ridges dominate the Suva Planina relief and they meet above the Kosmovac village and cross into the Valožje valley. The highest parts of the ridges are characterized by sharp, almost alpine peaks. The higher south-western ridge begins with the Koritnjak (above Niška Banja) and runs towards the southeast. The lower north-eastern ridge rises above the surface of Kunovica and runs towards the south (Петровић, 1954). The north-west part of Suva Planina is a chain from the Trem peak $(1,808 \mathrm{~m})$ to the Mosor peak $(985 \mathrm{~m})$, while the southern part of the mountain is characterized by peaks at a height of 1,000-1,700 m: Litica (1,683 m), Golemi vrh (1,535 m), Pasarelo (1,522 m), Divna Gorica (1,389 m), Glogov vrh (1,206 m) and other peaks (Новаковић-Костић, 2015). 
The Suva Planina relief is characterized by many Karst-based rich features such as sinkholes, caves, and pit caves (Нешић, 2015). Several pit caves have snow throughout the year and many of the discovered caves (Vekila vranovica, Orlova dupka, Ostrovička vranovica, Mala balanica, Ogorelačka pećina, Šuplja dupka) have been well researched but are not attractive for tourists (Станковић, 2014). There are also many underground geomorphological forms including cave residues and over 500 caverns (Краснић, 2005).

The geomorphologic features of the Suva Planina favor the development of AT because of: a denivelation that exceeds 1,300 m, sharp and inaccessible peaks, a terrain with good airflow, cliffs for climbing, and the Nišava River with fast waters. As a result, mountaineering, rafting, kayaking, rock climbing, paragliding and other such activities are possible on Suva Planina. However, they are very challenging for tourists and due to the risk and uncertainty, they require good preparedness and equipment. Many sinkholes and a terrain that's mostly limestone make it difficult to move but adventurers see the charm of a mountain relief that presents such obstacles.

The lower parts of Suva Planina are characterized by a humid continental climate. Plain-like climate (with special vegetation) is present in the altitude belt above $600-800 \mathrm{~m}$ while typical mountain climate is present only in the highest parts (Краснић, 2005). A limiting factor for AT development is the lack of weather stations on Suva Planina. Weather data are taken from measurements at weather stations in Niš and Bela Palanka. These data are often not precise, especially in autumn and winter when the changes of weather are sudden and difficult to predict.

The hottest month is July with a mean temperature of $20.6^{\circ} \mathrm{C}$, while January is the coldest with a mean temperature of $0.9^{\circ} \mathrm{C}$. The maximum relative humidity is in December, and the minimum in April (План управљања; Специјални резерват природе "Сува планина", 2016). The annual flow of cloudiness coincides with the annual flow of relative humidity. Winter months have high cloudiness with values above 6.5 , while summer months have moderate cloudiness (Милић, 1962). Many winds blow on the mountain and the most important are the local ones called dolnjak and gornjak. Gornjak is an eastern wind (with a very cold and devastating effect, especially in the winter when the temperature drops below the zero) while Dolnjak is a northwestern one (Дуцић и Анђелковић, 2006).

Suva Planina's climate is both stimulating and limiting factor for AT development. The climate and vegetation have a positive effect on people's psychology and physiology, especially in summer because temperatures are not as high due to higher altitude. In the spring and summer, the conditions for rock climbing, rafting, kayaking and mountaineering are most favorable and the combination of relief and wind in two locations is suitable for paragliding. Winter is a 
problem because temperatures drop below zero, the weather becomes very unstable and unpredictable, and the wind on the Devojački grob pass (The girl's grave in English) reaches hurricane strength. This prevents climbers from reaching the highest peak - Trem. It also happens that the strong winter wind (over 70 $\mathrm{km} / \mathrm{h}$ ) is accompanied by extremely thick fog, which reduces visibility between Devojački grob and Trem. In these conditions even the most experienced mountaineers give up the climb. However, many climbers see this as a great challenge and still try to conquer the mountain (despite the risk and uncertainty).

Suva Planina is water-less and this is typical on a terrain that's in the advanced stage of karst process development. The lack of water is due to a deep underground waterproof substrate. In contrast to lack of water on the limestone ridge, Suva Planina's foothills are abundant with water, especially those parts that face the surrounding structural basins (Милић, 1962). There are large rivers at the foothill: the Nišava river, the Koritnička river, the Lužnica river, the Kunovička river, the Studena river and the Crvena river.

The Nišava River is known for its Sićevaćka klisura (Eng. The Sićevo Gorge), which separates the Suva Planina in the south from the Svrljiške planine (Eng. Svrljig Mountains) in the north. On the cliffs of the gorge, the habitat has a strictly protected bird species - The golden eagle (Aquila chrysaetos) (Станковић, 2014). Due to its picturesque landscapes, with preserved natural ecosystems and unique flora and fauna, Sićevo Gorge was proclaimed as a Nature Park (II protection category) in 2000. It provides opportunities for hunting, fishing, kayaking, rafting, mountaineering and paragliding (Програм развоја туризма Града Ниша са акционим планом за период 2018-2020. године).

Different types of vegetation can be seen on Suva Planina. At the foothill there are Mediterranean and sub Mediterranean species, as well as temperate broadleaf and mixed forest, and at the highest peaks of the mountain are alpine species. Up to a height of $1,400 \mathrm{~m}$, Suva Planina has typical forest vegetation. After that, the landscape is that of grasses, sparse trees and pasture. However, although the diversity in plant species is high, Suva Planina is characterized by scarce forest vegetation (Петровић, 1954). There are more forests in the northern wetter regions, while the southern slopes are somewhat more humid in the lower zones (Bosnić, 2007).

The main features of floral diversity are endemic, relict, rare and endangered plant species. Josif Pančić discovered two endemic species in this area: Parietaria serbica and Ramonda nathaliae. These areas are the habitat of the tertiary relict of Ramonda serbica. Fauna is very endangered and has been decreasing for the last hundred years. Of the birds of prey, there are a small number of sparrows, hawks, northern goshawks, and falcons. In the forest there are foxes, wild boars, roe deers and wolves (Краснић, 2005). 
In 2015, a part of Suva Planina was placed under protection as a special nature reserve and declared a category 1 protected area of international and national significance (Уредба о проглашењу специјалног резервата природе „Сува планина“, 2015).There are three protection regimes:

1. Protection level 1 (4.68\% of the area) covering "Mosor" and "Sokolov kamen - Trem - Smrdan - Divna Gorica";

2. Protection level 2 (12.11\% of the area) covering "Valožje - Golemo Stražište" and "Rubovac - Cerje (Rebrine)";

3. Protection level 3 (83.21\% of the area).

\section{Demographic-social characteristics of Suva Planina}

On the slopes of Suva Planina and at its foothill, 75 settlements were formed at a height of $900 \mathrm{~m}$. Most of them are located in the contact zone of the basins and hills, which allows a number of benefits (presence of water, traffic availability, formation of villages, etc.).

Spatial distribution of settlements is conditioned mostly by altitude. Martinović and Matijević (2006) point out that due to the breakdown of the terrain and the altitude difference on Suva Planina the following hypsometric arrangement of the settlement is expressed: at the altitude from 200 to $400 \mathrm{~m}$ there are 24 settlements (32\%); at the altitude from 400 to $600 \mathrm{~m}$ there are 39 settlements (52\%); at the altitude from 600 to $900 \mathrm{~m}$ there are 12 settlements $(16 \%)$.

Suva Planina is part of a wider area (Region of South and East Serbia NUTS 2) (Golić \& Joksimović, 2017), which for years has been facing enormous regional problems. The extent to which the process of depopulation on Suva Planina is represented is best confirmed by one of the most recent research, which was done for the period from 1991 to 2015. In the observed period, among the municipalities with the largest decrease in the number of inhabitants in the whole territory of Serbia were Gadžin Han and Babušnica, located on the slopes of Suva Planina (Joksimović \& Golić, 2017).

Suva Planina faces major socio-demographic problems, which directly affect the possibility of developing all forms of tourism. The main problems are:

- Reduction of the average number of inhabitants;

- Continuous negative trend of population density;

- Unfavorable age structure (continuous reduction of the population under the age of 19, with simultaneous increase of the old population over 60 years);

- Demographic "dying" of rural settlements, especially at the altitude of over $500 \mathrm{~m}$ (the natural growth rate has been negative for many years, the migration balance also has a negative value); 
- Intensive decline in the utilization of natural and production potentials (Мартиновић и Матијевић, 2006; Просторни план подручја посебне намене Специјалног резервата природе Сува планина, 2010).

The main economic activities are forestry and traditional agriculture (farming, animal husbandry, beekeeping and collection of medicinal herbs and forest fruitage), while tertiary sector activities are poorly developed (trade, catering, tourism and transport) (Просторни план подручја посебне намене Специјалног резервата природе Сува планина, 2010).

\section{Types of adventure tourism on Suva Planina}

Suva Planina has exceptional features and forms of karst-based relief (Боснић, 2010) which are suitable for AT development. Although there's no generally accepted classification of adventurous activities, we can divide them into those that take place on the ground, in water and in the air. Table 2 presents the types of AT activities that can be done on Suva Planina. Certain activities have been partially implemented while others (due to inadequate infrastructure equipment) haven't.

Table 2. Types of adventure tourism on Suva Planina

\begin{tabular}{|c|c|}
\hline Activity Medium & Activity Type \\
\hline ground & $\begin{array}{c}\text { mountaineering (hiking, trekking), mountain biking, free climbing, } \\
\text { skiing, snowboarding, orientation, horse riding, speleo activities }\end{array}$ \\
\hline water & kayaking, rafting \\
\hline air & paragliding \\
\hline
\end{tabular}

The most frequent activity is mountaineering. Mountaineering is a movement along the man-made and natural mountain trails and paths. It requires personal and collective mountaineering equipment, clothing and footwear that provide protection, safe and free movement in all weather conditions. Hiking and trekking are types of mountaineering. The main difference is that hiking refers walking on marked paths and roads, while trekking is a more challenging activity that tests psycho-physical ability and endurance (PSS, 2018).

Many mountain trails lead to Trem (Suva Planina's highest peak) and although the paths to it are not very difficult, the northwest wind in the winter achieves hurricane speeds, making it difficult to reach Trem. When the air temperature is low and the snow is dry and needle-like, the ascent to Trem is a real feat. The first $500 \mathrm{~m}$ are not problematic (because the path runs through the forest on Suva Planina's eastern side) but with the arrival at Devojački grob (1,408 $\mathrm{m})$, the wind speed becomes so high that "every part of the body must be well 
protected, because the ice dust carried by a strong wind strikes painfully on unprotected skin" (Боснић, 2010).

Table 3. Mountaineering trails on Suva Planina ${ }^{3}$

\begin{tabular}{|c|c|c|c|c|c|c|c|c|c|}
\hline & $\underset{(\mathrm{m})}{\operatorname{Hmin}}$ & $\underset{(m)}{\operatorname{Hmax}}$ & $\begin{array}{l}\mathrm{L} \\
(\mathrm{m})\end{array}$ & $\begin{array}{l}\text { Lv } \\
(\mathrm{m})\end{array}$ & $\begin{array}{c}\mathrm{D} \\
(\mathrm{m})\end{array}$ & $\begin{array}{l}\Sigma \mathrm{D} \\
(\mathrm{m})\end{array}$ & $\begin{array}{l}\Sigma \mathrm{Ls} \\
(\mathrm{m})\end{array}$ & $\begin{array}{l}\text { Us } \\
(\%)\end{array}$ & $\underset{(\%)}{\operatorname{Umax}}$ \\
\hline Niška Banja - Trem & 218 & 1,810 & 19,854 & 18,139 & 1,592 & 2,260 & 893 & 7.5 & 73.6 \\
\hline $\begin{array}{l}\text { Gornja Studena- } \\
\text { Divljane }\end{array}$ & 340 & 1,810 & 30,101 & 19,149 & 1,470 & 2,137 & 2,099 & 0.19 & 65.04 \\
\hline $\begin{array}{l}\text { Gornja Studena } \\
\text { - Veta - Gornja } \\
\text { Studena }\end{array}$ & 389 & 947 & 14,025 & 89,6 & 558 & 1,023 & 1,008 & 16.6 & 43.9 \\
\hline $\begin{array}{c}\text { Bojanine vode - } \\
\text { Trem - Bojanine } \\
\text { vode }\end{array}$ & 833 & 1,810 & 13,704 & 12,882 & 977 & 1,413 & 1,417 & 15.4 & 98.6 \\
\hline $\begin{array}{l}\text { Bojanine vode - } \\
\text { Pasarelo }\end{array}$ & 833 & 1,810 & 13,661 & 12,270 & 977 & 1,783 & 1,165 & 5.03 & 99.6 \\
\hline $\begin{array}{l}\text { Gornja Studena } \\
\text { - Trem - Donji } \\
\text { Dušnik }\end{array}$ & 389 & 1,810 & 17,915 & 9,484 & 1,421 & 1,864 & 1,697 & 3.7 & 93.2 \\
\hline $\begin{array}{c}\text { Divljane - Pasarelo } \\
\text { - Divljane }\end{array}$ & 339 & 1,522 & 19,803 & 44,3 & 1,183 & 1,539 & 1,533 & 11.7 & 45.5 \\
\hline $\begin{array}{c}\text { Divljane - Mali } \\
\text { Krčimir }\end{array}$ & 339 & 1,476 & 17,560 & 11,176 & 1,137 & 1,444 & 1,137 & 2.7 & 59.2 \\
\hline $\begin{array}{c}\text { Veliki Vrtop - } \\
\text { Golemo Stražište }\end{array}$ & 628 & 1,681 & 5,394 & 3,903 & 1,053 & 1,079 & 92,7 & 26.2 & 79.7 \\
\hline $\begin{array}{c}\text { Mokra - Pasarelo - } \\
\text { Divljane }\end{array}$ & 317 & 1,522 & 19,605 & 3,866 & 1,205 & 1,638 & 1,529 & 2.8 & 48.4 \\
\hline $\begin{array}{l}\text { Mokra - Preslap - } \\
\text { Rženac - Mokra }\end{array}$ & 317 & 1,459 & 11,368 & 11,078 & 1,142 & 1,120 & 1,119 & 6.6 & 47.5 \\
\hline $\begin{array}{c}\text { Vrgudinac- } \\
\text { Pasarelo- - Divljane }\end{array}$ & 328 & 1,522 & 19,483 & 8,014 & 1,194 & 1,729 & 1,631 & 1.2 & 46.4 \\
\hline Mosor - Pasarelo & 708 & 1,810 & 16,564 & 14,937 & 1,102 & 2,013 & 1,328 & 4.2 & 98.6 \\
\hline Vrgudinac-Trem & 345 & 1,810 & 16,043 & 9,086 & 1,465 & 1,993 & 686 & 14.3 & 89.2 \\
\hline $\begin{array}{c}\text { Gornji Dušnik - } \\
\text { Trem - Bojanine } \\
\text { vode }\end{array}$ & 539 & 1,810 & 14,196 & 5,634 & 1,271 & 1,614 & 1,333 & 4.5 & 83.6 \\
\hline
\end{tabular}

Source: data processing in Global Mapper. Explanation: Hmin - minimum altitude, Hmax-maximum altitude, $\mathbf{L}$ - trail length, $\mathbf{L v}$ - air distance between the start and end of the trail, $\mathbf{D}$ - denivelation, $\boldsymbol{\Sigma} \mathbf{D}$ - total climb denivelation, $\boldsymbol{\Sigma} \mathbf{L s}$ - total climb length, Us - average climb, Umax - maximum climb

Table 3 mostly shows mountaineering trails based on the mountaineering and tourist map of the Mountaineering Association of Serbia. The exceptions are Veliki Vrtop - Golemo Stražište and Divljane - Mali Krčimir, which are processed on the basis of Mountaineering Club "Suva Planina" information. There are many trails that are not marked on the mountaineering and tourism map of the Mountaineering Association of Serbia. Also, there is the possibility of combining the trails processed in Table 3. 
Table 3 presents Suva Planina's mountaineering trails that are suitable for all types of recreational activities. High levels of technical and physical preparation is required for the following trails: Niška Banja - Trem, Gornja Studena - Divljane, Gornja Studena - Trem - Donji Dušnik, Vrgudinac - Trem, Gornji Dušnik - Trem - Bojanine vode. These trails feature a denivelation over 1,000 $\mathrm{m}$; therefore they are a real feat for mountaineering. Taking into account the average climb (Us), the steepest trails are the Veliki Vrtop - Golemo Stražište (26.2\%), Gornja Studena - Veta - Gornja Studena (16.6\%), Bojanine vode - Trem - Bojanine vode, $(15.4 \%)$ and Vrgudinac - Trem (14.3\%). Therefore, these trails are most suitable for hiking and mountaineering and we can place them in a group of "hard" adventure activities.

For mountain biking, the suitable trails are those which have an average climb of less than $15 \%$. Horse riding is suitable for trails with average climb up to 9\%: Niška Banja - Trem, Gornja Studena - Divljane, Bojane vode - Pasarelo, Gornja Studena - Trem - Donji Dušnik, Divljane - Mali Krčimir, Mokra Pasarelo - Divljane, Mokra - Rženac - Mokra, Vrgudinac - Pasarelo - Divljane, Mosor - Pasarelo, Gornji Dušnik - Trem - Bojane vode.

The most challenging trail is called the Niška transverzala (Niška Itinerary) and it's not presented in Table 3 because it requires additional explanations. The trail consists of a five-day tent tour of 59 hours $(12+15+8+15+9)$. It falls into very difficult trails and requires a high level of physical condition $(8 / 10)$ and technical preparation (6/10). The route is mostly marked, except from Divna Gorica to Vrgudinac and from Zeleni vrh do Plesa. One of the biggest problems on the road is lack of water because of limestone terrain (www.stazeibogaze.info).

Table 4. Trails of Niška transverzala

\begin{tabular}{|c|c|c|}
\hline Day 1 & $\begin{array}{l}\text { Niš - Velika Tumba - } \\
\text { Koritnjak }\end{array}$ & Total length $31,500 \mathrm{~m}$. \\
\hline Day 2 & $\begin{array}{l}\text { Koritnjak - Trem - } \\
\quad \text { Pasarelo }\end{array}$ & $\begin{array}{c}\text { Total length } 29,000 \mathrm{~m} \text {. It represents the hardest part on } \\
\text { the entire itinerary (altitude difference, unsuitable terrain } \\
\text { and water shortage). }\end{array}$ \\
\hline Day 3 & $\begin{array}{c}\text { Pasarelo - Divna Gorica } \\
\text { - Krupac }\end{array}$ & $\begin{array}{c}\text { Total length } 22,500 \mathrm{~m} \text {. The marking exists only to Divna } \\
\text { Gorica. }\end{array}$ \\
\hline Day 4 & $\begin{array}{l}\text { Krupac-Svrljig } \\
\text { Mountains- Oreovac }\end{array}$ & Total length $29,000 \mathrm{~m}$. \\
\hline Day 5 & $\begin{array}{l}\text { Oreovac - Kalafat - } \\
\text { Kamenički vis - Niš }\end{array}$ & $\begin{array}{c}\text { Total length } 31,000 \mathrm{~m} \text {. Trail is marked and represents the } \\
\text { easiest day. }\end{array}$ \\
\hline
\end{tabular}

Niška transverzala has a total road length of $143,000 \mathrm{~m}$. The road is demarcated at several points: KT1 - Niš Fortress (208 m), KT2 - Velika Tumba (903 m), KT3 - Koritnik (650 m), KT4 - Mosor (984 m), KT5 - Sokolov kamen (1,523 
m), KT6 - Trem (1,810 m), KT7 - Pasarelo (1,523 m), KT8 - Divna Gorica (1,389 m), KT9 - Zeleni vrh (1,334 m), KT10 - Pleš (1,267 m), KT11 - Gradac (1,062 m), Kalafat (838 m), KT13 Kamenički vis (800 m) (PSS, 2018).

There is one official cycling route around Suva Planina (with a length of $133,000 \mathrm{~m}$ ). The average time needed to complete the route is two days but cyclists who are in excellent physical condition can do it in one. There are 6 climbs on the road and there's almost no straight terrain (as seen on the elevation profile chart). It requires an average level of conditioning/preparedness $(5 / 10)$ (www.stazeibogaze.info).

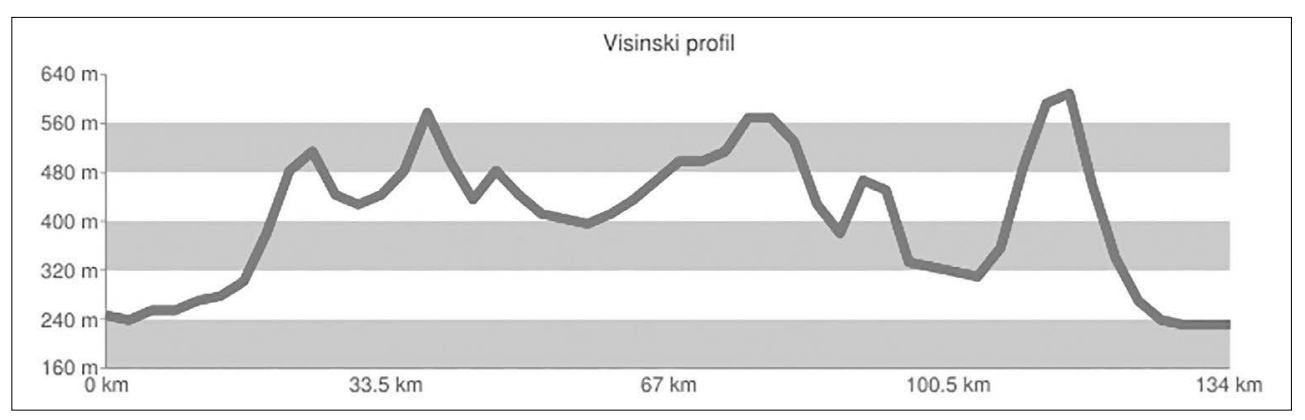

Chart 1. The elevation profile chart of cycling route

(Source: www.stazeibogaze.info)

Every year, the Naissus 018 Sports Association organizes the Suva Extreme Challenge. It's a unique sporting event where athletes, mountain racers and bikers gather. Depending on their readiness, bikers choose one of 2 trails. For the well-prepared there's a challenging $55 \mathrm{~km}$ long trail with a 2,400 m climb while for beginners, there's a marked $25 \mathrm{~km}$ long trail with a 1,080 m climb. The race starts in Niška Banja and goes across Crni Kamen, Bojanine vode, the Veta Monastery, Donja Studena, Koritnik, and ends in Niška Banja. For mountain racers there's a $15 \mathrm{~km}$ long track with a $800 \mathrm{~m}$ climb (SEC, 2018).

Not far from Niška Banja, the Nišava River has its left tributary Studena, better known as the Jelašnička River. It has created a limestone gorge and on its periphery are numerous cliffs suitable for climbing. Mountaineers, alpinists and nature lovers visit the gorge and due to its beauty and natural rarities, it was proclaimed as the Special Nature Reserve (I protection category) in 1995 (Станковић, 2014).

Jelašnička klisura (Jelasnička Gorge) is the first climbing center in Serbia dedicated to sports climbing. The first climbing paths were created in 1994. The wall is a sharp dolomite limestone. There are 58 directions for climbing, weights from $5 \mathrm{a}$ to $8 \mathrm{~b}+($ UIAA) and about 150 boulders weighing from 4 to $7 \mathrm{~b}+$ (UIAA). The directions are well marked but without a guide, a lot of orientation is re- 
quired (AOB, 2018). The climb is open throughout the year but due to its microclimate and the orientation of the rock, the best time for climbing is spring and autumn (the temperatures are too extreme in winter and summer). Every climbing path is given a name and the recommended ones are: All of this leads to me $6 b$, Before the rain $6 b+$, Mea Culpa $7 a+$, Ammonia $7 c$ (overhang of 45 degrees), $\mathrm{H} 2 \mathrm{O}$ $7 c+$ (considered as the most beautiful), Lumbago $6 b+$ (cracks, difficult access) (SKT, 2018). Climbing requires an average level of physical condition $(2 / 10)$ and technical preparation (4/10). Jelašnička Gorge hosts national competitions and Balkan Cups (Боснић, 2010).

Sićevačka klisura (Sićevo Gorge) is the highest climbing place in Serbia based on the height of the wall and on the number of climbing paths. Climbing in these parts of Serbia began in 1950 by the Serbian mountaineers who set the basic standards of climbing (AOB, 2018). Since 2010 - after the "Naissus route climbing challenge 04" competition (when 20 climbing paths were created) - Sićevo has started to have visits from sports climbers. The wall is south-oriented and the ideal periods for climbing are spring, autumn and sunny winter days (MCN, 2018). The walls are of limestone type, from 50 to $250 \mathrm{~m}$ in height, and the terrain configurations are different. There is a climbing guide which has 55 entries. There are also 10 new climbing paths (not mentioned in the guide) weighing from 3 to 7 and A-A2. In terms of beauty and experience, the following directions are highlighted: Ljubičasti san $(5 / 6,110 \mathrm{~m})$; Leva kobra $(5 / 6+, 250 \mathrm{~m})$ - long, exposed and difficult direction; Jo-jo (6/7-, $65 \mathrm{~m}) ;$ P.P. $(5+/ 6,150 \mathrm{~m})$ - combination of cracks, crossbars and grooves; Spomenica Nejcu (5+/6, 100 m) - one of the heaviest in the gorge (AOB, 2018).

The Nišava River is suitable for extreme water sports. The best place for these activities is Sićevo Gorge where European and state competitions in rafting and kayaking are organized $(\mathrm{ONB}, 2018)$. Rafting in the Sićevo Gorge is performed on the part of the river from Dolac to Ostrovica, where there is a rafting track. The length of the track is $7 \mathrm{~km}$, and the descent lasts about 3 hours, which depends on the height of the water level, the speed of the river and the rowing intensity. The Nišavski spust (Nišava descent) is well-known and it runs from the bridge located between Niška Banja and the village Prosek to the Vrežina pools in Niš. The length of the track is $8.5 \mathrm{~km}$, and the program lasts from 2 to 3 hours. Rafting programs in Nišava belong to easier (soft) programs. The main organizer of rafting is the "Safari Club" which provides boats, oars, helmets and vests. Nišavska Regatta is a widely known rafting event that's been carried out since 1996 (TON, 2018).

There is a ski resort called Bojanine vode (located at $864 \mathrm{~m}$ above sea level) on Suva Planina and because of its ideal location (at the foot of Sokolov kamen peak) it has snow throughout the whole winter. There are several ski slopes with ski lifts but they haven't been functional for years. According to the relevant 
authorities, they will be repaired. Ski slope Sokolov kamen is suitable for slalom competitions because of longitude of 1,000 m, with an altitude difference of 320 $\mathrm{m}$. The ski lift is $900 \mathrm{~m}$ long, $320 \mathrm{~m}$ high, and can serve 1,100 skiers per hour. The Pantina trail ski slope is 300 meters long, has a ski lift and night skiing lights, and is suitable for recreational skiers. The Studenac ski slope is best for children and beginners (www.skijanje.co.rs).

Due to favorable winds and good climate, Suva Planina's slopes are suitable for paragliding activities. There are European and international competitions organized on Suva Planina by the Grunf Paragliding Club (which promotes the development of paragliding in Niš and Serbia) (PKG, 2018). Paragliding is a type of recreational flying that involves a specific device - a paraglider - driven by the wind. The advantage of paragliding as a sport is that it doesn't require special physical abilities or a developed tourism infrastructure. The only preconditions are altitude of $200 \mathrm{~m}$ and the presence of wind (Pavić, Rančić \& Mijatov, 2013).

There are two places to take off from on Suva Planina: Koritnik and Višegrad. Koritnik is located $4 \mathrm{~km}$ from the center of Niška Banja and is recommended for beginners. Koritnik can be reached by a car and is located at $550 \mathrm{~m}$ above sea level (the paraglider landing is at altitude of $220 \mathrm{~m}$ ). Višegrad is located above the village of Sićevo and is intended for more experienced and brave people. The path that leads to the top of Višegrad (from where paragliders can take off) is at 1,020 m above sea level, and the landing is at $320 \mathrm{~m}$ (which makes an altitude difference of $700 \mathrm{~m}$ ). Competitions have been organized here since 1995 . The best flight time is from May to September, although it is possible to fly all year round (TON, 2018).

\section{Discussion and conclusion}

There isn't adequate infrastructure for adventure tourism on Suva Planina but it does have exceptional potential: natural beauty and attractive locations for adventure activities, clean air, and preserved natural environment. However, natural qualities are not enough for developing any type of tourism; they must be accompanied by adequate infrastructure and human resources. The main limitations for AT development on Suva Planina are negative demographic trends and inadequate tourism infrastructure (presented in more detail in Table 5). The existing tourism and recreational facilities on Suva Planina have not been sufficiently developed further. In some parts of the mountain, the road conditions are rather poor, which negatively affects transportational access and quality of stay. 
Table 5. SWOT analysis of adventure tourism on Suva Planina

\begin{tabular}{|c|c|}
\hline $\begin{array}{l}\text { Strengths: } \\
\text { - favorable geographical, traffic and tourist } \\
\text { position; } \\
\text { - proximity to the E-75 and E-80 highway; } \\
\text { - geomorphological characteristics of the } \\
\text { terrain suitable for development of AT (hiking, } \\
\text { biking, paragliding, free climbing, rafting, } \\
\text { kayaking etc.); } \\
\text { - the existence of profit (Nature Travel Office) } \\
\text { and non-profit organizations (Grunf paragliding } \\
\text { club, Mountain Club Suva Planina, Preslap, } \\
\text { Mosor and others) which offer AT services; } \\
\text { - preserved nature and a high degree of } \\
\text { biodiversity; } \\
\text { - existence of protected natural areas (Suva } \\
\text { Planina, Jelašnička Gorge, Sićevo Gorge); } \\
\text { - proximity to the City of Niš and the airport } \\
\text { "Constantine the Great”. }\end{array}$ & $\begin{array}{l}\text { Weaknesses: } \\
\text { - poor infrastructure and equipment; } \\
\text { - bad tourist signaling; } \\
\text { - poor maintenance of existing tourist facilities } \\
\text { and lack of accommodation capacities; } \\
\text { - depopulation area and unsatisfactory } \\
\text { demographic (aging settlements) and } \\
\text { educational structure (a large number of } \\
\text { illiterate); } \\
\text { - migration of the population; } \\
\text { - ruined ski slopes; } \\
\text { - low level of entrepreneurial spirit; } \\
\text { - lack of a strategy for the development of } \\
\text { sustainable forms of tourism; } \\
\text { - disturbance of animals by tourists, } \\
\text { mountaineers and domicile population; } \\
\text { - insufficient awareness of the population } \\
\text { about the protection of the environment and } \\
\text { the benefits of tourism development. }\end{array}$ \\
\hline $\begin{array}{l}\text { Opportunities: } \\
\text { - planned development of sustainable forms } \\
\text { of tourism, especially adventure tourism; } \\
\text { - revitalization of the ski resort Bojanine vode; } \\
\text { - promotion of area as a green zone in the } \\
\text { function of development of AT; } \\
\text { - renovation of existing ones and construction } \\
\text { of new tourist capacities; } \\
\text { - enrichment of the tourist offer for the visitors } \\
\text { of Niška Banja and Niš with the programs of } \\
\text { visiting Suva Planina; } \\
\text { - improvement of interregional cooperation } \\
\text { (Tourist Organization of Niš, Bela Palanka and } \\
\text { Gadžin Han and local self-governments which } \\
\text { are located on Suva Planina); } \\
\text { - training of personnel and awareness raising } \\
\text { on the importance of tourism development; } \\
\text { - preservation and improvement of objects of } \\
\text { geomorphologic heritage; } \\
\text { - improving the living conditions of the local } \\
\text { population. }\end{array}$ & $\begin{array}{l}\text { Threats: } \\
\text { - uncontrolled tourism development (group } \\
\text { size, retention time); } \\
\text { - degradation of the environment and } \\
\text { disappearance of some rare plant species } \\
\text { (Ramonda serbica, Ramonda nathaliae, Aquilegia } \\
\text { pancicii, Rosa serbica, etc.); } \\
\text { - deterioration of the demographic structure; } \\
\text { - insufficient and inadequate training of } \\
\text { tourist workers; } \\
\text { - erosive processes, landslides and slopes; } \\
\text { - inadequate disposal of municipal waste; } \\
\text { - failure to establish cooperation between local } \\
\text { self-governments; } \\
\text { - lack of investment and sustainable sources of } \\
\text { financing; } \\
\text { - lack of information on the natural and } \\
\text { cultural values of the population, which are } \\
\text { important for developing tourism in this area. }\end{array}$ \\
\hline
\end{tabular}

The topic of AT is a major part of the Tourism Development Program of the City of Niš (with an action plan for the time frame from 2018 to 2020). The Program has indicated that special interest tourism and active holidays must be included in the tourist product of the first category and that this form of tourism interweaves with other forms and is difficult to identify independently. The program also places special emphasis on the necessity to create a reputation of security when 
it comes to promotion of adventure tourism. Although there are many prominent adventure tourism projects in the program ("Nis Adventure", MTB bicycle race "Konstantin Trophy", mountain maze with the obstacles "The maze", construction of the cable car from Niška Banja to Koritnik, arrangement of Bojanine vode picnic area, "Adrenalin Park" with artificial wall, etc.), most of them are in long-term development and have not made significant progress.

In order to improve the conditions for AT development, the following measures should be taken:

- Renovation and modernization of existing tourist facilities (accommodation capacities on Bojanine vode, including Studenac mountain cabin, hotel "Trem" in Donji Dušnik, mountain cabins Celin kamen and Ploče, rural households);

- Repair of ski slopes, ski lifts and sports facilities at Bojanine vode so they can be used for skiing and specialized winter sports;

- Reorganization of nationally constructed buildings (old barns and abandoned houses) into tourist attractions/offer;

- Improving traffic infrastructure in order to increase accessibility for tourist facilities;

- Setting up traffic and tourist signaling, in particular, setting up information boards on the Special Nature Reserve "Suva Planina" with specified rules of visitors' behavior;

- Mapping locations of natural and anthropogenic value, as well as mapping locations for extreme sports, in order to inform visitors;

- Opening receptive tourist agencies that would offer adventure tourism services accompanied by trained guides;

- Development, education and engagement of local population in adventure and general tourism;

- Setting up weather stations for collecting climate data in order to determine suitable weather conditions for research activities on Suva Planina;

- Presentation of adventure activities by the tourist organizations of Niš, Gadžin Han and Bela Palanka.

The construction and renovation of appropriate tourist infrastructure may have negative consequences for the environment, especially considering the fact that a large part of Suva Planina has been declared a special nature reserve. Therefore, AT must be strategically planned so that the proposed solutions would be compatible with sustainable development of the area. Due to the smaller volume of visitors, as well as the rules/laws that support respecting Suva Planina's natural environment, the development of AT would bring 
a number of benefits to the local community and the natural environment. It is necessary to engage the local population and to control the number of visitors who due to their volume (over 1,000 mountaineers traditionally attending the annual winter climb of Trem), can negatively affect the natural environment and thus jeopardize the qualities of the Special Nature Reserve "Suva Planina".

\section{Acknowledgements}

The paper is part of a research project (no. 176008) funded by the Ministry of Education, Science and Technological Development of the Republic of Serbia.

\section{References}

AOB (2018). Alpinistički odsek "dr Rastko Stojanović" Planinarski savez Beograd. Retrieved from http://www.aob.org.rs

Beedie, P., \& Hudson, S. (2003). Emergence of mountain-based adventure tourism. Annals of Tourism Research, 30(3), 625-643.

Bosnić, D. (2007). Srbija na izvoru. Beograd: Intersistem.

Боснић, Д. (2010). Чудесна Србија. Београд: Младинска књига.

Buckley, R. (2006). Adventure Tourism Research: A Guide to the Literature. Tourism Recreation Research, 31(2), 75-83.

Bruckley, R. (2007). Adventure tourism products: Price, duration, size, skill, remoteness. Tourism Management, 28(6), 1428-1433.

Buckley, R. (2010). Adventure tourism management. Butterworth-Heinemann: Amsterdam.

Buckley, R. (2012). Rush as a key motivation in skilled adventure tourism: Resolving the risk recreation paradox. Tourism Management, 33(4), 961-970.

Carnicelli-Filho, S., Schwartz, G. M., \& Tahara, A. K. (2010). Fear and adventure tourism in Brazil. Tourism Management, 31(6), 953-956.

Chen, C. M., Lin, Y. L., \& Chang, T. T. (2016). The effects of macroeconomic and weather conditions on the business cycle of Taiwan's adventure tourism. Current Issues in Tourism, 20(5), 447-454.

Дуцић, В., и Анђелковић, Г. (2006). Климатологија - практикум за географе. Београд: Географски факултет.

EkoSpark (2018). Suva planina - Trem, Sokolov kamen, Mosor. Retrieved from http:// ekospark.com

Ferguson, J.Y. (1998). Location and Design of Recreational Trails: Application of GIS Technology. Blacksburg, USA: Faculty of the Virginia Polytechnic Institute. 
Gašović, M. (2017). Avanturistički planinski turizam u Crnoj Gori. Matica, 70, 429458.

Giddy, J. K., \& Webb, N. L. (2016). The influence of the environment on motivations to participate in adventure tourism: The case of the Tsitsikamma. South African Geographical Journal, 98(2), 351-366

Golić, R., \& Joksimović, M. (2017). Regionalization of Serbia as an instrument of balanced regional development and reduction of regional inequalities. Collection of Papers - Faculty of Geography at the University of Belgrade, 65(1a), 209-226.

Јоксимовић, М. (2016). Специирични облици туризма у функцији развоја Горњег Полимља. Београд: Географски факултет, докторска дисертација.

Joksimović, M., \& Golić, R. (2017). Indicators of regional inequality in Serbia. Collection of Papers - Faculty of Geography at the University of Belgrade, 65(1a), 227249.

Jovičić, D. (2010). Turizam i životna sredina. Novi Beograd: Ton Plus.

Краснић, Т. (2005). Сува планина. Годищњи билтен природњачког друштва ГЕА, бр. 5.

Lăzuran, A., \& Ungureanu, M. (2014). Adventure tourism an insufficiently exploited opportunity in Bihor County, Romania. Analele Universității din Oradea, Seria Geografie, 24(1), 44-54.

Lötter, M., Geldenhuys, S., \& Potgieter, M. (2012). Demographic profile of Adventure tourism in Pretoria. Global Journal of Business Research, 6(4), 97-109.

Mackenzie, S. H., \& Kerr, J. H. (2012). A (mis)guided adventure tourism experience: An autoethnographic analysis of mountaineering in Bolivia. Journal of Sports $\mathcal{E}$ Tourism, 17(2), 125-144.

Мартиновић, М., и Матијевић, Д. (2006). Неке просторно-демографске развојне тенденције насеља Суве планине. Гласник Српског географског друштва, 86(1), 133-140.

MCN (2018). Marketing centar Niš. Retrieved from http:/ / welcometonis.com

Милић, Ч. (1962). Главне одлике краса Суве планине. Зборник радова Географског института "Јован Цвијић“, 18, 93-152.

Mu, Y., \& Nepal, S. (2016). High Mountain Adventure Tourism: Trekkers' Perceptions of Risk and Death in Mt. Everest Region, Nepal. Asia Pacific Journal of Tourism Research, 21(5), 500-511.

Нешић, Д. (2015). Рељеф у пределу врха Литица (Сува планина, Источна Србија). Зборник радова „Достигнућа, актуелности и изазови географске науке и праксе“. Београд: Географски факултет, 173-178.

Новаковић-Костић, Р. (2015). Национална туристичка географија. Ужице: Висока пословно-техничка школа струковних студија.

ONB (2018). Opština Niška Banja. Retrieved from http://www.goniskabanja.org.rs 
Pavić, L., Rančić, M., \& Mijatov, M. (2013). Potential for Paragliding Tourism Development in Niška Banja (South Serbia). Turizam, 17(3), 110-120.

Петровић, J. (1954). Ерозија тла на Сувој планини. Зборник радова Географског завода, Свеска I, 28-53.

PKG (2018). Paraglajding klub Grunf. Retrieved from http:/ /www.grunf.org

План управљања за период 2016-2025. године; Специјални резерват природе „Сува планина“ (2016). Нови Београд: Сектор за шумарство и заштиту животне средине. Retrieved from http://www.srbijasume.rs/pdf/nacrt.plan. upravljnja\%20suva\%20planina.2016.-2025..pdf

Програму развоја туризма Града Ниша са акционим планом. (2017). Retrieved from http://www.ni.rs/wp-content/uploads/Nacrt-Programa-razvojaturizma-Grada-Ni\%C5\%A1a-sa-akcionim-planom-za-period-2018-2020.-godine. pdf

Просторни план подручја посебне намене Специјалног резервата природе Сува планина, Службени гласник Републике Србије, бр. 42/10.

PSS (2018). Planinarski savez Srbije. Retrieved from https://pss.rs/

Rokenes, A., Schumann, S., \& Rose, J. (2015). The Art of Guiding in Nature-Based Adventure Tourism - How Guides Can Create Client Value and Positive Experiences on Mountain Bike and Backcountry Ski Tours. Scandinavian Journal of Hospitality and Tourism, 15(1), 62-82.

Schott, C. (2007). Selling Adventure Tourism: A Distribution Channels Perspective. International Journal of Tourism Research, 9(4), 257-274.

SEC (2018). Suva Extreme Challenge. Retrieved from http:// naissus018.org

SKT (2018). Sportski klub „Tribe”. Retrieved from http://serbianclimbing.com

Soutar, N. G., \& Williams, P. (2009). Value, Satisfaction and behavioral intentions in an adventure tourism context. Annals of Tourism Research, 36(3), 413-438.

Spalević, A., \& Igračev, N. (2011). The natural-geographical basics for the development of the adventure tourism in Serbia. Journal of the Geographical Institute "Jovan Cvijić" SASA, 61(3), 137-150.

Станковић, С. (2014). Бисери Србије. Нови Сад: Православна реч.

Стефановић, В. (2010). Екстремни спортови као део туристичке понуде Србије. Зборник радова Географског факултета - Универзитета у Београду, LVIII, 111120.

TON (2018). Turistička organizacija Niš. Retrieved from http://visitnis.com

Trajković, S, Trajković, P., \& Ivanković, M. (2013). Insufficiently utilized natural tourist resources of Southern Serbia. Journal of Process Management - New Technologies, International, 1(3), 68-81.

UNWTO (2014). Global Report on Adventure Tourism. Madrid: UNWTO. 
Уредба о проглашењу специјалног резервата природе „Сува планина“, Службени гласник Републике Србије, бр. 72/15.

Vujadinović, S. et al. (2013). Possibilities for mountain-based adventure tourism: the case of Serbia. Bulletin of Geography. Socio-economic Series, 19, 99-111.

www.stazeibogaze.info

www.skijanje.co.rs 